\title{
癒着性イレウスに小承気湯が奏効した一例
}

\begin{tabular}{|c|c|c|c|}
\hline 八木 清貴 ${ }^{a}$ & 岡 & 洋志 ${ }^{a}$ & 野上 \\
\hline 井上 博喜a & 中田 & 真司 ${ }^{a}$ & 野崎 \\
\hline 網 宏彰a & $\begin{array}{l}\text { 後藤 } \\
\text { 嶋田 }\end{array}$ & $\begin{array}{r}\text { 博三 } a \\
\text { 豊 } a\end{array}$ & 柴原 \\
\hline
\end{tabular}

a 富山大学大学院医学薬学研究部和漢診療学講座, 富山, ₹930-0194 富山市杉谷2630

b 富山大学和漢医薬学総合研究所漢方診断学部門, 富山, =930-0194 富山市杉谷2630

\section{A Case of Adhesive Ileus Successfully Treated with Shojokito}

\author{
Kiyotaka YAGI $^{\mathrm{a}} \quad$ Hiroshi OKA $^{\mathrm{a}}$ Tatsuya NOGAMI ${ }^{\mathrm{a}}$ \\ Hiroki INOUE $^{\mathrm{a}}$ Sinji NAKADA $^{\mathrm{a}} \quad$ Kazuya NOZAKI $^{\mathrm{a}}$ \\ Hiroaki HIKIAMI $^{\mathrm{a}} \quad{\text { Hirozo } \text { GOTO }^{\mathrm{a}} \text { Naotoshi SHIBAHARA }}^{\mathrm{b}}$ \\ Yutaka SHIMADA $^{\mathrm{a}}$
}

a Department of Japanese Oriental (Kampo) Medicine, Graduate School of Medicine and Pharmaceutical Sciences, University of Toyama, 2630 Sugitani, Toyama 930-0194, Japan

b Department of Kampo Diagnostics, Institute of Natural Medicine, University of Toyama, 2630 Sugitani, Toyama 930-0194, Japan

\begin{abstract}
We report a case of recurring adhesive ileus that was successfully treated with shojokito (decoction) without inserting a nasogastric tube. The patient was a 75-year-old male who had been treated for abdominal symptoms in our department after a laparotomy. He visited our hospital mainly for complaints of abdominal pain and distention, was diagnosed with adhesive ileus because of a niveau image upon abdominal X-ray, and was hospitalized the same day. We diagnosed him as Yang syndrome and excess syndrome because he had thick yellow fur of the tongue, and administered shojokito. He broke wind at 40 minutes after administration of shojokito, and had bowel movement two hours later. Furthermore, he had mass diarrhea after another administration of this formula, and the niveau image disappeared the next day. It is often considered that an ileus develops with Cold, for which daikenchuto is prescribed frequently. However, in some cases cold purgative formulas such as jokito group may be effective, if such cases are Yang syndrome and excess syndrome, and present with yellow fur of the tongue.
\end{abstract}

Key words : adhesive ileus, shojokito, yellow fur of the tongue, cold purgative formula, jokito group

\section{要旨}

反復する癒着性イレウスに小承気湯（煎薬）を投与し，イレウス管を挿入することなく早期に改善した症例を経 験した。症例は75歳の男性で, 開腹術後の腹部症状のため当科外来に通院していた。腹痛, 腹満を主訴に当科を受 診した際，腹部レントゲン写真上 niveau を認めたため,イレウスと診断され入院となった。舌に厚い黄苔を認め たことから，陽証かつ実証と診断し小承気湯を投与した。一服後40分で転失気があり，2 時間後に排便を認めた。 さらに一服後大量の下痢便を認め, 翌曰には niveau は消失した。イレウスは寒によって起こることが多いとされ 大建中湯が頻用されるが，舌に黄苔を被った陽証のイレウスには承気湯類などの寒下剤で下すことで改善する症例 もあると考えられた。

キーワード : イレウス，小承気湯，黄苔，寒下剤，承気湯類

\section{緒言}

開腹術後の癒着性イレウスは，時に治療に難渋す る。しかしながら，絶食，経鼻胃管挿入による減圧 療法に加えて，大建中湯をはじめとする漢方治療の
併用の有効性を示す報告が認められる ${ }^{122)}$ 。小承気湯 は陽明裏実の証に使用される方用であり, 腹満や便 秘が使用目標となるが，イレウスの治療に使用され た報告はみられない。今回我々は，癒着性イレウス 
表 1 入院時の血液生化学検査所見

\begin{tabular}{llllclr}
\hline WBC & 7000 & $/ \mu \mathrm{L}$ & ALT & $21 \mathrm{IU} / \mathrm{L}$ & $\mathrm{BUN}$ & $19 \mathrm{mg} / \mathrm{dL}$ \\
$\mathrm{RBC}$ & $448 \times 10^{4}$ & $/ \mu \mathrm{L}$ & AST & $10 \mathrm{IU} / \mathrm{L}$ & $\mathrm{Cr}$ & $1.2 \mathrm{mg} / \mathrm{dL}$ \\
$\mathrm{Hb}$ & 14.3 & $\mathrm{~g} / \mathrm{dL}$ & $\mathrm{LDH}$ & $141 \mathrm{IU} / \mathrm{L}$ & $\mathrm{UA}$ & $5.9 \mathrm{mg} / \mathrm{dL}$ \\
$\mathrm{Ht}$ & 42.5 & $\%$ & ALP & $209 \mathrm{IU} / \mathrm{L}$ & $\mathrm{Na}$ & $136 \mathrm{mEq} / \mathrm{L}$ \\
$\mathrm{PLT}$ & $21.0 \times 10^{4} / \mu \mathrm{L}$ & $\gamma$-GTP & $20 \mathrm{IU} / \mathrm{L}$ & $\mathrm{K}$ & $4.1 \mathrm{mEq} / \mathrm{L}$ \\
& & & T-Bil & $1.1 \mathrm{mg} / \mathrm{dL}$ & $\mathrm{Cl}$ & $100 \mathrm{mEq} / \mathrm{L}$ \\
& & & TP & $7.3 \mathrm{~g} / \mathrm{dL}$ & $\mathrm{FPG}$ & $111 \mathrm{mg} / \mathrm{L}$ \\
& & AMY & $146 \mathrm{IU} / \mathrm{L}$ & $\mathrm{CRP}$ & $0.1 \mathrm{mg} / \mathrm{L}$ \\
& & TC & $182 \mathrm{mg} / \mathrm{dL}$ & $\mathrm{CEA}$ & $1.6 \mathrm{ng} / \mathrm{mL}$ \\
& & & TG & $71 \mathrm{mg} / \mathrm{dL}$ & $\mathrm{CA} 19-9$ & $98 \mathrm{ng} / \mathrm{mL}$ \\
\hline
\end{tabular}

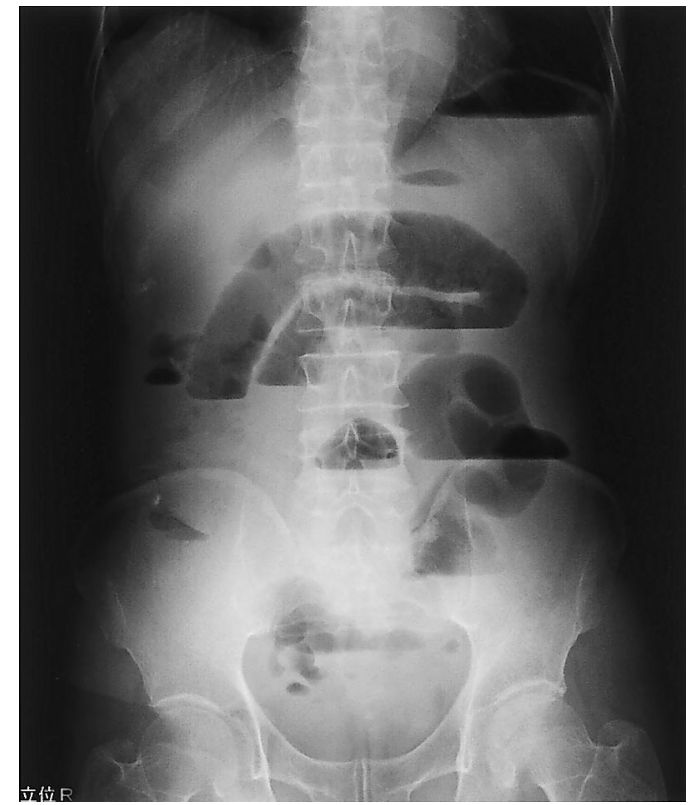

立位

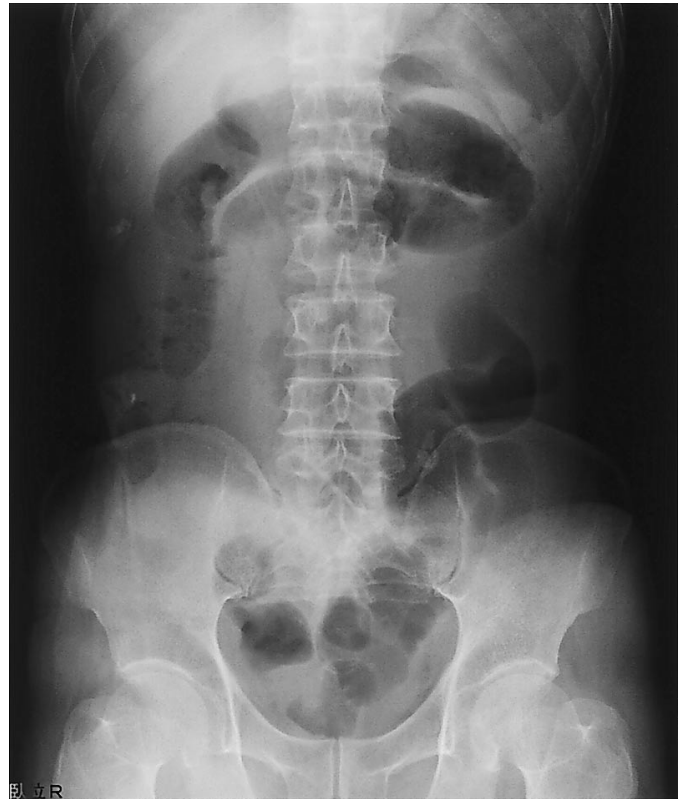

臥位

図 1 入院時の腹部単純レントゲン写真

患者に小承気湯を投与したところ，経鼻胃管を挿入 することなく早期に改善した症例を経験したので報 告する。

\section{症例}

75歳, 男性

主訴 : 腹痛, 腹部膨満感

家族歴：特記すべきことなし

既往歴：44歳膀胱癌にて膀胱全摘術, 回腸導管造 設, 46歳癒着剥離術, 49歳肺腫瘍切除術, 73歳左腎 摘出術。

現病歴：44歳時の開腹手術後より癒着性イレウス を繰り返し，62歳より当科外来に通院中であった。 しかし，その後もしばしば腹痛発作を認め入退院を 繰り返していた。最近では2003年11月にイレウスで 入院加療した際には, 治療に難渋しイレウス管の挿
入を要した。その後大建中湯エキスと小建中湯エキ スの併用で小康状態であったが，2006年 5 月，夕食 後より上腹部痛が出現した。翌日より排ガスの停止, 腹部膨満感，腹痛を認めたため，当科を緊急受診し た。腹部レントゲン写真にて niveauを認めたため, イレウスの診断のもと同日入院となった。

入院時現症：身長 $163.5 \mathrm{~cm}$, 体重 $49.4 \mathrm{~kg}$ 。血圧 155 $/ 82 \mathrm{mmHg}$, 脈拍 $70 /$ 分・整。体温 $36.7^{\circ} \mathrm{C}$ 。頭頸部に 異常なし。心音・呼吸音正常。腹部は軟で, 下腹部 はやや膨満し, 下腹部中心に軽い圧痛を認めたが, 筋性防御, 反跳痛は認めなかった。腸蠕動音は充進 し金属音を呈していた。下腹部正中, 左腰部の開腹 手術創痕と右下腹部にウロストーマを認めた。下腿 には軽度の浮腫を認めた。

入院時検査所見：血液生化学検査を表 1 に示した。 


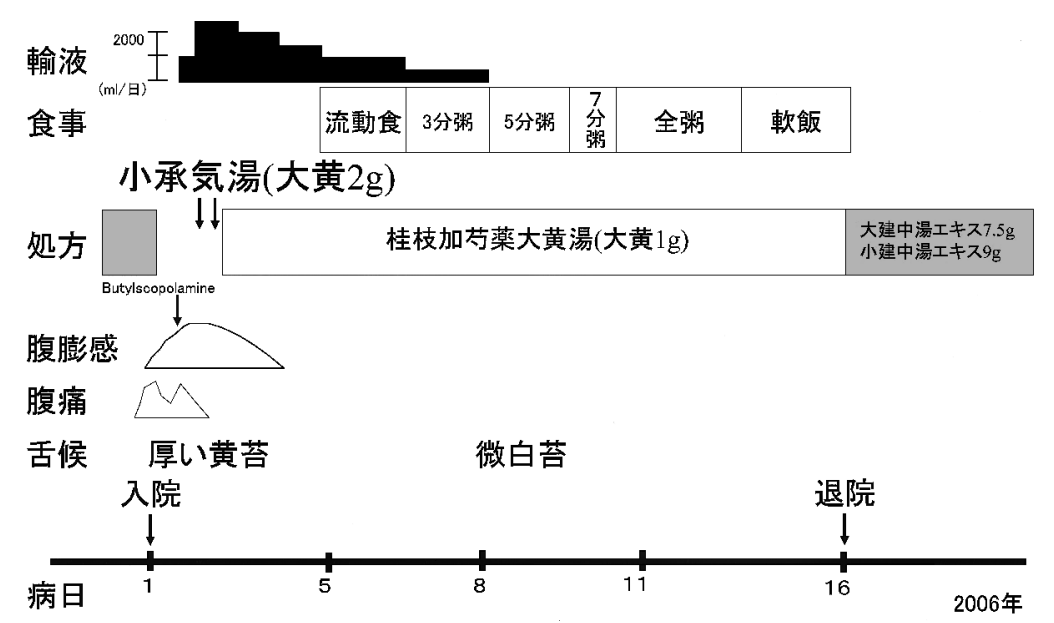

図 2 臨床経過

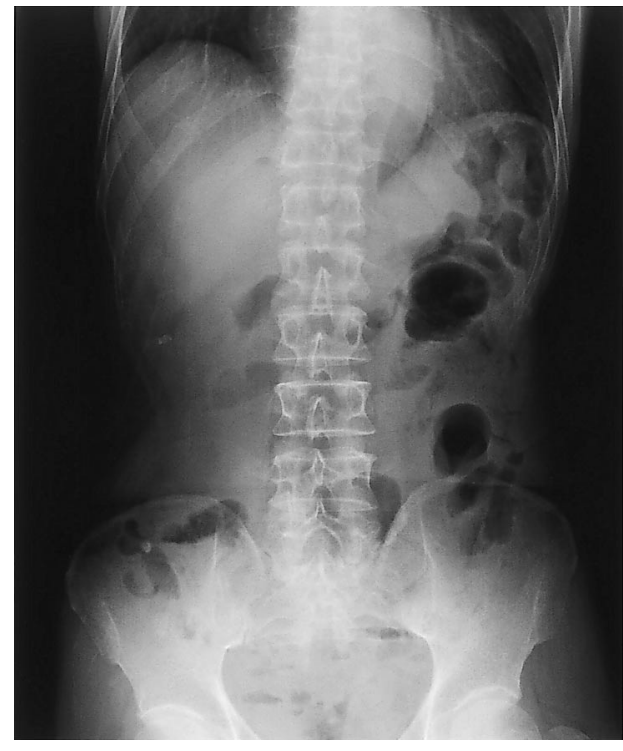

立位

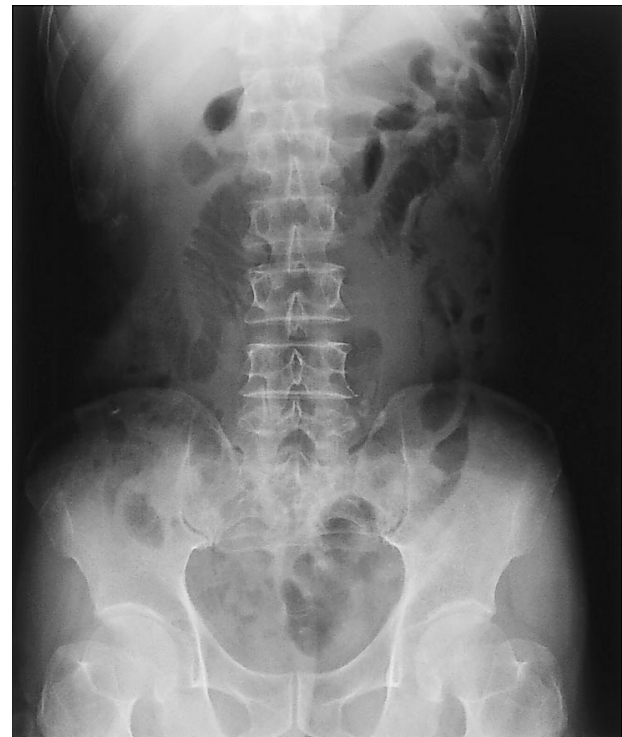

臥位

図 3 治療後の腹部単純レントゲン写真

CA19-9 は軽度上昇していたが, 以前と比較し著変 はなかった。その他は特に異常は認めなかった。腹 部単純レントゲン写真では立位で niveauを認め, 臥位で小腸ガス像を認めた（図 1 )。

漢方医学的所見：自覚症状では，悪寒はなく，熱 感と口渇を認めた。腹満と間欠的な腹痛を訴えたが， 嘔気はなかった。他覚所見では, 脈候はやや沈・や や実・緊であった。舌候は暗赤色で，厚い乾燥した 黄苔を被っていた。腹候は, 腹力中等度で, 両側腹 直筋が軽度攣急し，下腹部は膨満し体表に熱感を認 めた。その他，自汗を認め，パウチ内には濃縮尿が 貯留していた。

治療経過：絞扼性イレウスの所見は認めず，癒着 による単純性イレウスと診断し保存的治療を行うこ
とにした。入院後の治療経過を図 2 に示した。絶食 のうえ補液を行い，夜間に腹痛を訴えたため，ブチ ルスコポラミンの筋注を行った。漢方医学的には, 外来処方の大建中湯エキスと小建中湯エキスの服用 中にもかかわらず発症したイレウスで, 寒よりむし ろ熱が主体の病態で, 厚い黄苔や腹診所見より陽証 かつ実証と判断し，小承気湯を投与した。投与後約 40分で排ガスがあり，2 時間後には排便を認めたが， 腹痛の増悪はみられなかった。さらに，小承気湯を もう一服したところ, 大量の水様下痢便を認め, 翌 日には腹満, 腹痛が改善した。腹部レントゲン所見 も改善し, niveauは消失した（図３）。二服のみで 小承気湯の後服はとどめ, 腹直筋攣急, 軽度残存し た腹満と圧痛を目標に桂枝加药薬大黄湯に転方した。 
表 2 イレウスに使用された陽証の方剤の報告例

\begin{tabular}{|c|c|c|c|c|c|c|}
\hline & 著者 & 年齢/性 & 報告年 & 手術歴 & 舌苔 & 処方 \\
\hline 1 & 原ら & 73/女 & 1983 & + & 記載なし & 調胃承気湯 \\
\hline 2 & 原ら ${ }^{8)}$ & 65/女 & 1983 & - & 黄苔 & 調胃承気湯 \\
\hline 3 & 原ら & 79/女 & 1983 & - & 記載なし & 調胃承気湯 \\
\hline 4 & 原ら & 70/女 & 1983 & - & 記載なし & 調胃承気湯 \\
\hline 5 & 仲原ら ${ }^{9)}$ & 73/女 & 1995 & + & 厚い黄苔 & 大承気湯 \\
\hline 6 & 趙ら ${ }^{13)}$ & 58/女 & 1996 & + & 厚い黄苔 & 大承気湯 \\
\hline 7 & 鄭ら & 45/男 & 1981 & + & 記載なし & 桃核承気湯 \\
\hline 8 & 河合ら ${ }^{12)}$ & 65/男 & 1981 & + & 黄苔 & 桃核承気湯 \\
\hline 9 & 関ら ${ }^{11)}$ & 57/女 & 1985 & + & 記載なし & 桃核承気湯 \\
\hline 10 & 関ら & 56/男 & 1985 & + & 記載なし & 桃核承気湯 \\
\hline 11 & 関ら & 25/女 & 1985 & + & 記載なし & 桃核承気湯 \\
\hline 12 & 関ら & 50/女 & 1985 & + & 記載なし & 大黄牡丹皮湯 \\
\hline 13 & 関ら & 65/女 & 1985 & + & 記載なし & 大黄牡丹皮湯 \\
\hline 14 & 関ら & 56/女 & 1985 & + & 記載なし & 柴胡桂枝湯 \\
\hline 15 & 自験例 & 77/男 & 2006 & + & 厚い黄苔 & 小承気湯 \\
\hline
\end{tabular}

転方後も服用毎に泥状便を認め，食事開始後も腹部 症状の増悪はなく, 第 8 病日には舌の厚い黄苔は微 白苔となった。経過良好のため第16病日退院となっ た。退院後は外来処方の大建中湯エキス $7.5 \mathrm{~g} /$ 日と 小建中湯エキス $9 \mathrm{~g} /$ 日に戻し, 便秘時に桂枝加药薬 大黄湯エキス $2.5 \mathrm{~g}$ を頓服するように指示したが, 現在（2007年 1月）に至るまで経過は良好である。

\section{考察}

今回使用した小承気湯は傷寒論を原典とし，陽明 病編には「若し，腹大いに満ちて通ぜざる者は，小 承気湯を与え，微しく胃気を和すべし。大いに泄下 に至らしむること勿れ。と記載されており ${ }^{3)}$ ，陽明 裏実の腹満便秘に用いられる方剤である。また,「陽 明病，潮熱，大便微しく硬き者は，小承気湯を与う ベし。若し大便せざること六七日なるは, 恐らくは 燥屎あらん。之を知らんと欲するの法は，少しく小 承気湯を与え, 湯腹中に入り, 転失気の者は此燥屎 あるなり。乃ち之を攻むべし。若し転失気せざる者 は，此れ但初頭硬く，後必ず溏し，之を攻むべから ず。云々」とあり，類聚方広義頭注にも「小承気湯 を与え以て之を和す。是一時の制機の治のみ。故に 与うと曰いて，之を主るとは曰わず。」とあ゙"。即 ち, 小承気湯は今回の症例のように, 腹満, 便秘で 下すかどうか迷った時，経過をみる方剤として使用 できると考えられる。

転失気の解釈に関しては，(1)転矢気の誤りで放屁
では無いという説，(2)原文の通り転失気で放屁であ るいう説，(3)転矢気の誤写であるが放屁を意味する という説, (4)吉益東洞の見解（この条文は後人の竄 入で，転失気の有無によって承気湯の適応症を定め るなどということをすべきでないという説）の 4 通 りの説がある5 承気湯投与後約40分で排ガスを認めたという経過か ら，転失（矢）気=放屁と解釈することが可能であ り，排ガスの有無がさらに攻下するか否かの指針と なり得ると考えられた。

腹部開腹術後に種々の苦痛を訴えるものは腹部術 後症候群と総称されており, その中に癒着性イレウ スも含まれる ${ }^{6)}$ 。細野らは腹部術後症候群を東洋医 学的に考えると, 「手術は, 腎虚を進め, 気血両虚 になり, 裏寒に陥り, 手術部位に疼血を生じ, 疝症 候群が発症しやすくなる」と述べている7。このこ とからも，中焦を温める大建中湯が術後に頻用され ることが理解できる。我々の調べた限りでは，過去 の報告においてイレウスに使用された漢方方剂は, 全157件の報告中，大建中湯は130件で約 $83 \%$ 占め ていた。その他, 桂枝加莐薬湯が 5 件, 中建中湯が 4 件，解急蜀椒湯が 3 件と温補剤が約 $95 \%$ を占めて いた。一方，イレウスに使用された陽証の方剤の報 告例を検討してみると，小承気湯を用いた報告例は 認めず，その他の承気湯類と大黄を含む駆疠血剤を 使用していた。そのうち舌苔所見が記載されている 


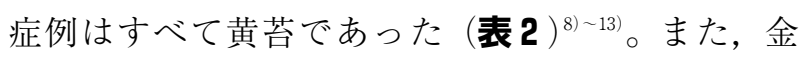
賈要略の腹満寒疝宿食病編には ${ }^{14)}$, 「病者, 腹満ち, 之を按じて痛まざるを虚と為し，痛む者を実と為す。 之を下すべし，舌黄にして未だ下さざる者は，之を 下せば黄自ずから去る。と記載されており, 黄苔 が下す指針となり得ることを示唆している。本症例 では，イレウスに対して臨機の処置として小承気湯 を投与したが，このことの妥当性を示すものと考え られる。

今回経験した症例と過去の報告例 ${ }^{81}$ などから考察 して以下のように考えてみた。先に示した細野らの 腹部術後症候群の記述からも言えるように, 開腹手 術後はもともと裏寒があり ${ }^{7}$, 術後のイレウスは寒 から始まると考える。そこに新たに寒邪が入り腸管 運動低下し食物は停滞する。すると熱を持ちだし， 消化管に熱をもつと舌黄になる。この段階になると 温剤で温めるのは望ましくなく，寒類下凨等で下し た方が良いと考える。しかしながら，イレウスが改 善しても漫然と寒類下剤を投与し続けるとまた裏が 冷えてイレウスに陥る事となるので改善すれば温郕 に変更するのが良いと考える。つまりイレウスの予 防（コントローラー）としては大建中湯をはじめと した温補郕，イレウスが起こってしまい舌黄となれ ば，リリーバーとして承気湯類などの寒類下剤を考 慮するのが良いと考える。大黄を有効に用いた随一 の名医とされる呉又可の『温疫論 ${ }^{15 \rrbracket} に も$ 舌の白苔 が次第に黄苔に変わり, 目が赤く, 小便が赤いのは 下してもいい証であると述べている。しかしながら いきなり大承気湯を投与するのは躊踷することもあ り，まず小承気湯を投与して転失気がでれば攻下せ しめる。転失気を認めなければ，攻下せず腹が張っ て食せずの太陰病期の大綱と考え, 桂枝加药薬大黄 湯や温下剤等で経過観察する方法が考えられる。本 症例は臨機の処置として（その後の方向性を見極め るのに）小承気湯を投与することの意義を確認でき た点で興味ある症例と思われた。

\section{結語}

繰り返す癒着性イレウスに小承気湯を投与し早期 に改善した症例を経験した。腸閉塞は寒によって起 こることが多いとされ，温剤である大建中湯などが 頻用されるが，舌に厚い黄苔を認める陽証かつ実証 のイレウスは承気湯類で下すことで改善する症例も あり得ると考えられた。
附記 : 本論文の要旨は第32回日本東洋医学会北陸支 部例会（福井，2006年10月）にて報告した。

本報告で使用した処方の構成生薬の分量・集散地は 以下の通りである。

小承気湯: 大黄 $2.0 \mathrm{~g}$ (中国), 枳実 $4.0 \mathrm{~g}$ (中国), 厚 朴 $4.0 \mathrm{~g}$ (日本)。

エキス製鼡はツムラを使用した。

\section{文献}

1 ）森脇義弘, 山本俊郎, 片村宏, 他: 大建中湯の単 純性腸閉塞への有用性に関する臨床的検討, 日東 医誌，43，63-68（1992）

2 ) 古川良幸, 川崎成郎, 中尾誠利, 他 : 腸閉塞に対 する大建中湯の治療効果. 基礎と臨床, 日東医誌, 54, 538-542 (2003)

3 ) 大塚敬節 : 傷寒論解説, 361-367, 創元社, 大阪 (1966)

4 ) 藤平健主講 : 類聚方広義解説, 350-365, 創元社, 大阪 (1999)

5 ) 矢数道明：漢方治療百話 第 2 集，672-680, 医 道の日本社，横須賀（1965）

6 ）鍋谷欣一, 李思元: 腹部術後症候群の現代医学的 考察，現代東洋医学，9，19-23（1988）

7 ) 細野完爾 : 腹部術後症候群の漢方治療概論, 現代 東洋医学，9，11-17 (1988)

8 ) 原敬二郎, 山下青史朗 : 老人患者のイレウス合併 に対する漢方薬治療の経験，日東医誌，33，3540 (1983)

9 ）仲原靖夫：陰陽弁証を誤って惹起したと思われる 腸閉塞症の一例. 腸閉塞のメカニズムの東西医学 的考察，漢方の臨床， 42，17-22（1995）

10）鄭為克, 村田和武：桃核承気湯による術後癒着性 イレゥスの一治験例, 漢方医学, 5, 12-14（1981）

11）関正威：手術後癒着性腸狭窄症および関連症状の 漢方製剂による外来治療経験，埼玉医科大学雑誌， 12, 129-137 (1985)

12）河合知則：イレウスに対する桃核承気湯の効果, 漢方診療，9，36-39（1990）

13）趙樹紅：麻疩性腸閉塞に大承気湯, 漢方の臨床, 43, 2116-2117 (1996)

14）大塚敬節主講：金檟要略講話, 216-248, 創元社, 大阪 (1979)

15）呉有性: 温疫論, 311-325, 出版総合研究所, 東 京 (1980) 